\title{
Yield And Quality Of Potato As Affected By Foliar Spraying Of Boron And Cytokinin
}

Since 1996

\author{
Smaher Malek ${ }^{1}$, A. I. A. Ebido ${ }^{1}$, G. Abdel-Nasser ${ }^{2}$, M. M. Ziton ${ }^{3}$ and A. A. \\ A. Gabel ${ }^{1}$
}

1. Plant Production Dept., 2. Soil and Agricultural Chemistry Dept.,3. Food Sciences Dept. Faculty of Agriculture Saba Basha, Alexandria University

$$
\text { DOI: } 10.21608 / \text { jalexu.2021.177195 }
$$

Article Information

Received:January $24^{\text {th }} 2021$

Revised: January $25^{\text {th }} 2021$

Accepted:April $25^{\text {th }} 2021$

Published: June $6^{\text {th }} 2021$

ABSTRACT: Two field experiments were carried out during the summer seasons of 2018 and 2019, at the Experimental Farm of Faculty of Agriculture (Saba- Basha) at Abees area, Alexandria University, Egypt, to study the effect of foliar application of the various levels of both BA as cytokinin and Boron on vegetative growth, yield, and quality of ' Hermes' potato cultivar.

Cut seedy explants were, approximately, $40 \mathrm{~g}$ in weight and each seedy explant contained 2 eyes planted on the $20^{\text {th }}$ February du ring both seasons. Cutting seeds were planted under a drip irrigation system at $30 \mathrm{~cm}$ apart in the row and $0.8 \mathrm{~m}$ width in dry soil then irrigated. The experimental plot consisted of two rows with $10.00 \mathrm{~m}$ long and $0.80 \mathrm{~m}$ width; making an area of $16.00 \mathrm{~m}^{2}$.

The experimental design was a split-plot- design in a randomized complete block. The main plots allocated for boron levels $\left(0,10,20\right.$, and $\left.30 \mathrm{mg} \mathrm{l}^{-1}\right)$. Whereas, the sub-plots were occupied by 6-benzyl adenine levels $\left(0,10,20\right.$, and $\left.30 \mathrm{mg} \mathrm{l}^{-1}\right)$.

The results indicated that foliar application of boron at $30 \mathrm{mg} \mathrm{l}^{-1}$ gave the highest average values of No. of tubers per plant, tuber fresh weight $\left(\mathrm{g} \mathrm{plant}^{-1}\right)$, No. of tubers per $10 \mathrm{~kg}$, total yield per plant (g) as well as total yield; (ton $\mathrm{fed}^{-1}$ ) compared to control plants during both seasons of the study. On the other side, foliar application of cytokinin at $30 \mathrm{mg} \mathrm{l}^{-1}$ recorded the highest of No. of tubers per plant, tuber fresh weight $\left(\mathrm{g} \mathrm{plant}^{-1}\right)$, No. of tubers per $10 \mathrm{~kg}$, total yield per plant (g) as well as total yield; (ton fed ${ }^{-1}$ as compared with control treatment and the other treatments, during both seasons.

Results of this characteristic revealed that applying boron at $30 \mathrm{mg}^{-1}$ increased significantly the potato chips defect $(\%)$, tuber firmness, tuber dry weight (\%), and specific gravity compared to the control treatment during both seasons. Besides, applying cytokinin at $30 \mathrm{mg} \mathrm{l}^{-1}$, produced higher potato chips defect (\%), tuber firmness, tuber dry weight (\%), and specific gravity as compared with untreated plants (control), during both seasons.

Foliar application of boron at $30 \mathrm{mg} \mathrm{l}^{-1}$ recorded the best results of tubers quality content i.e., average values of starch, tuber sugars, TSS, and ascorbic acid of potato tuber as compared with control treatments, during both seasons, also, potato plants treated with 30 $\mathrm{mg} \mathrm{l}^{-1}$ of cytokinin gave the highest mean values of the average values of starch, tuber sugars, TSS and ascorbic acid of potato tuber as compared with control treatments, during both seasons.

Keywords:foliar application, potato crop, boron spray, cytokinin, tuber yield, tuber quality

\section{INTRODUCTION}

Potato (Solanum tuberosum L.) has an important economic role in Egypt, because of its role in the enrichment of the Egyptian economy by exporting potatoes. However, Egypt imports, annually, from 50000 to 55000 tons of potato seeds from the northwest European countries, particularly from Netherland and England planted in the summer season in January up to the middle of February. The fall and the winter plantation seeded with the stored seeds from the summer crop production, besides, a part of the summer crop exported to European and Arabian countries, and the rest of the crop is stored to supply the local market for consumption.
Cytokinins are plant hormones (upon biosynthesized endogenously), and plant growth regulators (upon biosynthesized exogenously), briefly, both promoting cell division and differentiation. Since the discovery of the first cytokinin, kinetin, by Miller et al. (1955), the number of chemicals compatible with the definition of cytokinins has grown to include a large array of natural and synthetic compounds, adenine and phenyl urea derivatives. The phenyl ureas constitute a group of synthetic cytokinins, some of which are highly active, e.g. CPPU [N-(2chloro-4-pyridyl) -N'- phenylurea] (Takahashi et al., 1978) and thidiazuron (Mok et al., 1982). 
Boron (B) also plays an important role in cell wall synthesis, sugar transport, cell division, cell development, auxin metabolism, good pollination and fruit set, seed development, synthesis of amino acids and proteins, nodule formation in legumes, and regulation of carbohydrate metabolism (El-Dissoky and AbdelKadar, 2013).

The availability of boron in soil affected considerably by soil $\mathrm{pH}$. At low $\mathrm{pH}$, most of the boron compounds are soluble but in the case of sandy soils having low $\mathrm{pH}, \mathrm{B}$ is lost down the profile by leaching if rainfall is high. It occurs mostly in the organic matter in the surface soil and down the profile B content decreases. Under drought conditions, the deficiency of boron observed due to the lower availability of B in subsoils (Prasad et al., 2014).

Therefore, the present research was conducted to 1) evaluate the potato cultivar (Hermes) for tuber productivity and quality, 2) find out the optimal doses of cytokinin (6-BA) and boron levels as foliar applications to improve yields and economical returns to potato growers, and 3) examine the interaction effect between 6 BA and boron levels.

\section{MATERIALS AND METHODS}

2.1. Experimental site and arrangement:

Two field experiments were carried out during the summer seasons of 2018 and 2019, at the Experimental Farm of Faculty of Agriculture (Saba- Basha) at Abees region, Alexandria University, Egypt, to study the effect of foliar application of the various levels of both BA (as cytokinin) and Boron on vegetative growth, yield, and quality of ' Hermes' potato cultivar.

Before planting, random soil samples of 0 $30 \mathrm{~cm}$ depth from different places of the planting field were collected and analyzed for some important chemical and physical properties as given in Table (1) according to the methods reported by Carter and Gregorich (2008).

\subsection{Potato cultivation}

The plant material of this investigation was Hermes cultivar which was exported from Scotland. Cut seedy explants were, approximately, $40 \mathrm{~g}$ in weight and each seedy explant contained 2 eyes planted on the $20^{\text {th }}$ February during both seasons. Cutting seeds were planted under a drip irrigation system at $30 \mathrm{~cm}$ apart in the row and 0.8 $m$ width in dry soil then irrigated. The experimental plot consisted of two rows with 10.00 $\mathrm{m}$ long and $0.80 \mathrm{~m}$ width; making an area of 16.00 $\mathrm{m}^{2}$.

Table (1). Some physical and chemical properties of the experimental site during both seasons of the experimentation (2018 and 2019).

\begin{tabular}{|c|c|c|}
\hline \multirow{2}{*}{ Soil properties } & \multicolumn{2}{|c|}{ Season } \\
\hline & 2018 & 2019 \\
\hline \multicolumn{3}{|l|}{ Mechanical Analysis: } \\
\hline Clay $(\%)$ & 50.68 & 50.30 \\
\hline Silt $(\%)$ & 10.00 & 10.70 \\
\hline Sand $(\%)$ & 39.32 & 40.00 \\
\hline Textural class & Clay & Clay \\
\hline pH (1:2 water suspension) & 8.10 & 8.20 \\
\hline $\mathrm{EC}$ at $25^{\circ} \mathrm{C}(\mathrm{dS} / \mathrm{m})$ & 1.15 & 1.20 \\
\hline \multicolumn{3}{|c|}{ Soluble cations ( $1: 5$, soil: water extract) meq/l } \\
\hline $\mathrm{Ca}^{++}$ & 3.08 & 3.02 \\
\hline $\mathrm{Mg}^{++}$ & 3.00 & 3.12 \\
\hline $\mathrm{K}^{+}$ & 0.60 & 0.65 \\
\hline $\mathrm{Na}^{+}$ & 4.65 & 5.01 \\
\hline \multicolumn{3}{|c|}{ Soluble anions $(1: 5$, soil: water extract $) \mathrm{meq} / \mathrm{l}$} \\
\hline $\mathrm{HCO}_{3}^{-}$ & 1.91 & 2.11 \\
\hline $\mathrm{Cl}^{-}$ & 8.41 & 9.15 \\
\hline $\mathrm{SO}_{4}^{--}$ & 1.03 & 1.25 \\
\hline $\mathrm{CaCO}_{3}(\%)$ & 31.57 & 31.60 \\
\hline Available $\mathrm{N}$ (mg/kg soil) & 98.23 & 95.50 \\
\hline Available P (mg/kg soil) & 18.00 & 18.25 \\
\hline Available K (mg/kg soil) & 1000 & 1050 \\
\hline
\end{tabular}




\subsection{The experimental treatments and design}

Treatments consisted of two factors (two independent variables) as a foliar applicants, i.e.; four concentrations of Boron (B) as boric acid $\left(\mathrm{H}_{3} \mathrm{BO}_{3}\right)\left[\mathrm{MW}=61.83 \mathrm{~g} \mathrm{~mol}^{-1}\right]$ contained $17 \% \mathrm{~B}$ i.e. 0 (control), 10, 20 and $30 \mathrm{mg} . \mathrm{l}^{-1}$ and four concentrations of synthetic Cytokinin or 6-benzyl adenine (BA) $\left[\mathrm{MW}=225.255 \mathrm{~g} \mathrm{~mol}^{-1}, \mathrm{C}_{12} \mathrm{H}_{11} \mathrm{~N}_{5}\right.$ ] as 0 (control), 10, 20 and $30 \mathrm{mg} \cdot \mathrm{l}^{-1}$ separately and in combinations. Control plants sprayed with distilled water. The BA and Boric acid purchased from El Gomhouria Company for Chemicals, Alexandria, Egypt. All precautions and accuracy followed during weighing, dissolving, spraying of both independent variables. Foliar application of both $\mathrm{B}$ and $\mathrm{BA}$ was done afternoon during both seasons, to avoid deterioration caused by the effect of higher temperatures and ambient atmosphere on the applied items, at the time of application. Both conducted experiments were factorial experiments layout in a randomized complete block design (RCBD), with four replicates. Each replicate included 16 treatments. All determined treatments distributed randomly within each block. Potato plants sprayed with the allocated or assigned treatments twice during the growing seasons, the first one was at 60 days (at the stage when the plants had approximately 12-15 leaves) after planting. The second application was 15 days after the first one (or when plants had approximately 25 30 leaves). The recommended agricultural practices for commercial potato production followed. Harvesting accomplished after 120 days of planting during both years.

\subsection{Experimental data collections}

Ten plants from each treatment in each replication taken randomly and tagged for records of the total yield and tubers quality parameters.

\subsubsection{Yield and its component measurements}

1.4.1.1. Number of tubers per plant was determined just after harvesting time (120 days from planting) using the average number of tubers of 10 plants.

2.4.1.2. Average tuber fresh weight (g) was determined immediately after harvesting, by dividing the weight of tubers yield by tuber's number of 10 plants.

2.4.1.3. The number of tubers $/ 10 \mathrm{~kg}$, was determined by taking a random sample of $10 \mathrm{~kg}$ of tubers from the yield of each treatment and then counted. The number of potato tubers / $10 \mathrm{~kg}$ is a character of the processing companies to receive potatoes. The accepted range of the number of tubers / $10 \mathrm{~kg}$ is $72-112$ tubers (Frito Lay Company, 1999), more than these numbers mean small tubers and consequently small slides of chips that reduce the chip quality. If it was less than that range it means the presence of over-size large tubers, which may comprise hallow hart and cracks. Such defects may cause the rejection of the chips after processing.

2.4.1.4. Average tuber yield per plant (g/plant) calculated using the average weight of tubers of 10 plants.

2.4.1.5. Total tubers yield per feddan (ton/fed) was determined via the yield of the plot, which weighed, then converted into tons per feddan.

\subsubsection{Tubers quality:}

2.4.2.1. Chips defect evaluation, was calculated by showing the size limits $(1 / 2 \mathrm{~cm})$ for sugar browning and defects using chip - check chart method to determine the internal, external and undesirable color defects and dividing the defects into three categories; the first green from $0-8 \%$ defects are acceptable potato chips, the second yellow $8-15 \%$ defects are acceptable potato chips but with discarding the percentage over $8 \%$ and the third red $>15 \%$ defects are rejected and not suitable for processing according to (Frito Lay Company, 1999).

2.4.2.2. Firmness measure (Newton "N"): It was measured using UC. Firmness-tester (Li and Kader, 1999).

Pound-force (lbs) x $4.448=$ Newton $(\mathrm{N})$.

2.4.2.3. Tubers dry weight (\%) was carried out via randomly tuber samples of $100 \mathrm{~g}$ of fresh weight which were dried in an electrical oven at $70^{\circ} \mathrm{C}$ till the constant weight, then the obtained value of tuber dry weight was calculated as a percentage.

2.4.2.4. Total soluble solids (TSS \%), or degrees Brix $\left(\mathrm{Bx}^{\circ}\right)$ is numerically equal to the percentage of sugar and others dissolved in a solution. This scale used in the food industry for measuring the approximate amount of sugars in fruit juices. Therefore, a solution that is 25 degrees Brix has $25 \mathrm{~g}$ of sugar per $100 \mathrm{~g}$ of solution (Majiid $\boldsymbol{e t}$ al., 2011). It estimated in the juice of the fresh tubers using a hand refractometer according to AOAC (1992). The calibration of the device done with a drop of distilled water. The reading adjusted to Brix ${ }^{\circ}$ using the small setscrew on the back. Verifying the accuracy achieved with a drop of 5 or $10 \%$ sucrose solution (5 grams' sugar in $100 \mathrm{ml}$ of distilled water). Prism rinsed between samples with distilled water and dried with soft paper tissues. Ten readings recorded per treatment.

2.4.2.5. Vitamin C (Ascorbic acid), the tubers' vitamin $\mathrm{C}$ was measured by titration with iodide potassium according to the method of Ranganna (1986) and calculated as $\mathrm{mg}$ vitamin C /100 g, f.w. 2.4.2.6. Specific gravity, was determined using the method described by Dinesh $\boldsymbol{e t}$ al. (2005) and calculated from the equation of Smith (1977) as follows: 


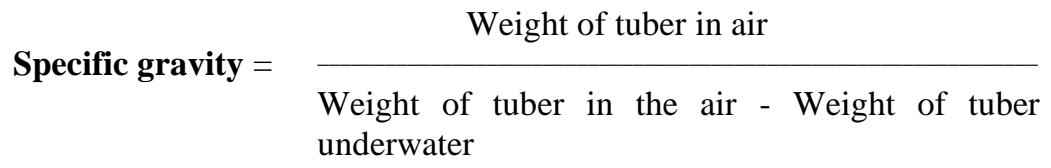

\subsubsection{Starch, reducing, non-reducing and total} sugars (\% D.W.) were determined for each tuber' sample according to the method described by Malik and Singh (1980).

2.4.4. Nutrients content of tubers $(N, P, K$, and $B)$ : 2.4.4.1. Tuber nitrogen content $(\%)$ was determined in digested plant material colorimetrically by Nessler's method (Chapman and Pratt, 1978) using Nessler solution (35 g KI /100 ml, D.W. + $20 \mathrm{~g} \mathrm{HgCl}_{2} / 500 \mathrm{ml}$, D.W + $120 \mathrm{~g} \mathrm{NaOH} / 250 \mathrm{ml}$, D.W.).

2.4.4.2. Tuber phosphorus content (\%) was determined calorimetrically using the vanadate method from the solution obtained through wet digestion as described by Singh et al. (2005).

2.4.4.3. Tuber potassium content $(\%)$ was measured using a flame photometer from the solution obtained through wet digestion as described by Singh et al. (2005).

2.4.4.4. Tuber boron content (\%) was determined colorimetrically by the Azomethine- $\mathrm{H}$ method at a spectrophotometer at wavelength $420 \mathrm{~nm}$ (Wolf, 1971).

\subsection{Statistical Analysis}

All obtained data of the present study were, statistically, analyzed according to the design used by the MSTAT-C computer software program (Bricker, 1991) and were tested by analysis of variance. The revised least significant difference test at 0.05 level of probability was used to compare the differences among the means of the various treatment combinations as illustrated by Duncan (1955) and Gomez and Gomez (1984).

\section{RESULTS AND DISCUSSION}

All treatments under study significantly $(p \leq 0.05)$ affected with the foliar application of Boron and BA as cytokinin, and their interactions during 2018 and 2019 growing seasons of the study.

Results presented under four main headings as follows: tuber yield characters, tuber physical quality characters, tuber chemical quality characters, and tubers $\mathrm{N}, \mathrm{P}, \mathrm{K}$, and $\mathrm{B}$ contents.

\subsection{Tuber yield characters}

Yield components of potato tubers in the expression of No. of tubers per plant, tuber fresh weight (g plant ${ }^{-1}$ ), No. of tubers per $10 \mathrm{~kg}$, total yield per plant (g) as well as total yield (ton fed $\mathrm{f}^{-1}$ ) as affected by foliar application with BA as cytokinin, boron and their interaction are presented in Table (2) for both seasons. Statistical analysis showed that using B at $30 \mathrm{mg} \mathrm{l}^{-1}$ was superior and associated with the highest mean values of all the aforementioned traits compared to the control treatment. For example the increasing of tuber fresh weight was (19.37 and $18.34 \%$ ) and for total yield, ton/fed was (107.29 and $123.25 \%$ ), respectively in 2018 and 2019 growing seasons. The same trend realized for the other yield components during both seasons.

This positive effect of $B$ in tuber yield parameters due to the low concentrations of $B$ availability and low organic matter $\%$ in the soil before planting as shown in Table (1), in addition to the important roles of B in the plant (cell division, sugar transport, synthesis of amino acids and proteins,....etc). Moreover, these results are following that obtained by Awad and Mansour (2007); El-Dissoky and AbdelKadar (2013), and Muthanna et al. (2017).

Concerning the effect of foliar application of BA as cytokinin on the mean values of yield and yield components of potato plants, data of Table (2) showed significant increases in all parameters under the study for the plants treated with any levels compared with the untreated plants, and the mean values of such traits still over than that obtained from the control treatment. In this respect, the highest mean values $(8.67,115.67$, $87.24,1002.86$, and 16.71) were realized for the treatment of $30 \mathrm{mg} . \mathrm{l}^{-1}$ cytokinin, while the lowest one $(5.75,99.66,100.56,573.05$, and 9.55) were recorded for the untreated plants for No. of tubers per plant, tuber fresh weight $\left(\mathrm{g} \mathrm{plant}^{-1}\right)$, No. of tubers per $10 \mathrm{~kg}$, yield per plant $(\mathrm{g})$, and total yield (ton $\mathrm{fed}^{-1}$ ), respectively during the season of 2018. The same trend obtained in the season of 2019 
Table (2). Average values of some yield characters of potato plants cv. 'Hermes' as affected by foliar application with Boron (B), Cytokinin (6-BA) and their combinations during the summer seasons of 2018 and 2019.

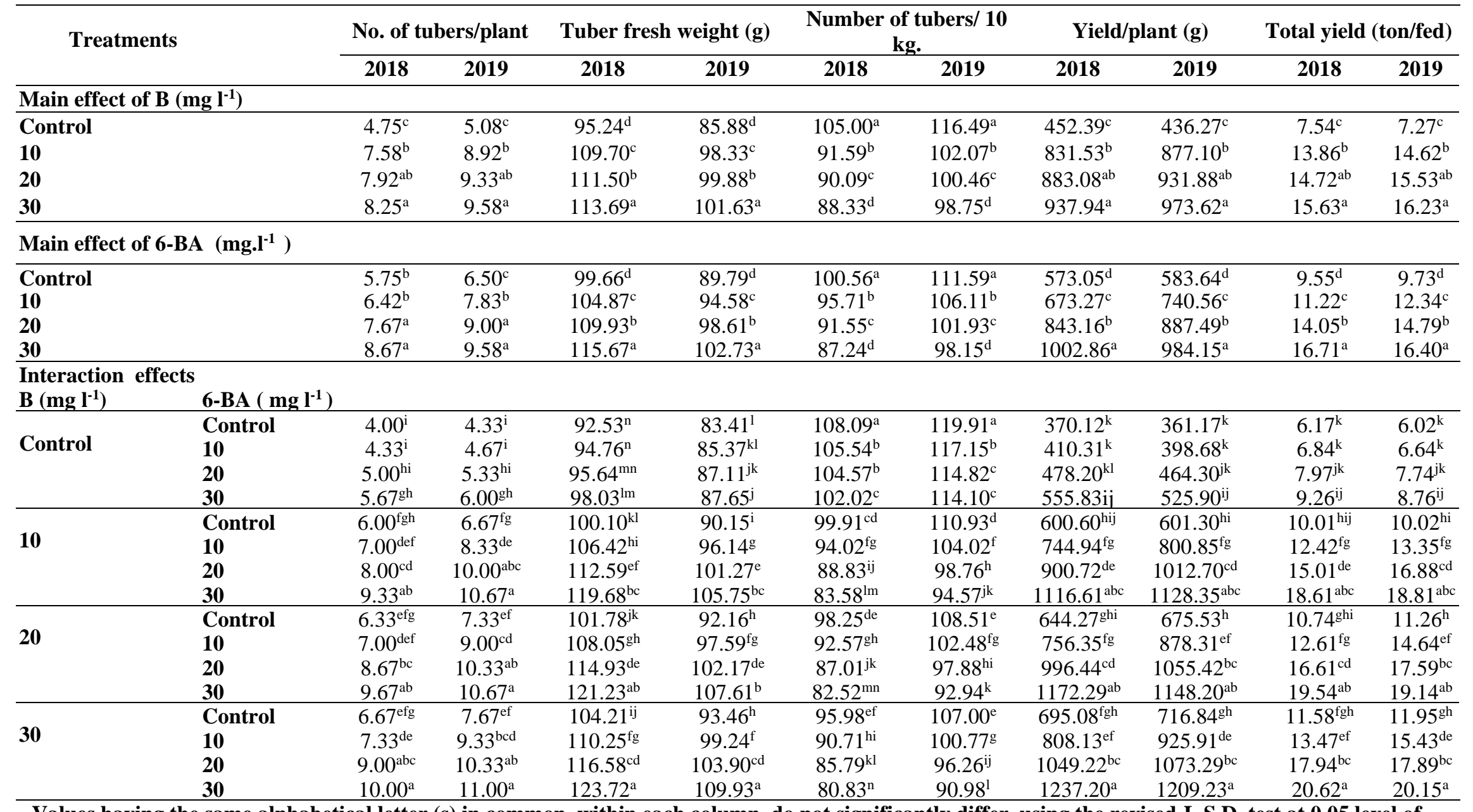

- Values having the same alphabetical letter (s) in common, within each column, do not significantly differ, using the revised L.S.D. test at 0.05 level of probability. 
The present results are in agreement with those obtained by several authors (Roumeliotis et al., 2012; Kolachevskaya et al., 2015 and 2017) who declare that cytokinin can accelerates and improves potato tuberization. In addition, Liu and Xie (2001) declared that various concentrations of cytokinin increased the size and weight of mini-tuber potato. The results also in agreement with those obtained by El-Shraiy and Hegazi (2010) who reported that the highest mean values of tubers fresh and dry weights, obtained by CPPU as cytokinin at 20-ppm treatment, which led to an increase in yield values. In the same arrangement, Njogu et al. (2015) reported that an increase in the level of cytokinin as BA, led to, significant, increase in the number of tubers per plant and yield (ton/ha).

The interaction effect between boron and cytokinin was significant in both seasons (Table 2). Spraying both boron and cytokinin at $30 \mathrm{mg} \mathrm{l}^{-1}$, resulted in the highest mean values of no. of tuber/plant, tuber fresh weight, no. of tuber/10 kg, yield/plant, and total yield (ton/fed) in both seasons.

\subsection{Tuber physical quality characters}

Data in Table (3) indicated the quality of the tubers, which, were expressed as potato chips defect $(\%)$, tuber firmness, tuber dry weight $(\%)$, and specific gravity as affected by foliar application with boron, $\mathrm{BA}$ as cytokinin, and their interactions in the growing seasons of 2018 and 2019.
Table (3) illustrated the effect of boron as a foliar application on the tuber physical quality characters as potato chips defect $(\%)$, tuber firmness, tuber dry weight $(\%)$, and specific gravity. Foliar application of boron increased significantly all tuber morphological parameters with increasing boron levels. All traits recorded a highly significant increase over control treatment and the highest mean values achieved at 30 mg. $\mathrm{l}^{-1}$ from boron. The rate of increase was 85.79, $17.09,14.18$, and $2.03 \%$ for potato chips defect (\%), tuber firmness $(\mathrm{N} / \mathrm{mm})$, tuber dry weight $(\%)$, and specific gravity, respectively during the season of 2018. The same trend obtained in the season of 2019. The enhanced dry matter production may attribute to the greater accumulation of photosynthesis products by vegetative parts. These effects of boron foliar spray on the previous parameters of potato quality may refer to the role of boron on sugar transport to parts of storage (tubers), also to its role in the synthesis of proteins and regulation of carbohydrate metabolism. These results are following that obtained by those El-Banna and Abd El-Salam (2005), Awad and Mansour (2007), El-Dissoky and Abdel-Kadar (2013). All of them studied the effect of boron on potato plant and they found that the quality of potato tuber parameters (i.e. dry matter, specific gravity, and tuber firmness) significantly increased with foliar B application 
Table (3). Average values of some quality determination of potato tubers cv. 'Hermes' characteristics as affected by foliar application with Boron (B), Cytokinin (6-BA) and their combinations during the summer seasons of 2018 and 2019.

\begin{tabular}{|c|c|c|c|c|c|c|c|c|c|}
\hline \multirow{2}{*}{\multicolumn{2}{|c|}{ Treatments }} & \multicolumn{2}{|c|}{$\begin{array}{l}\text { Potato chips defect } \\
(\%)\end{array}$} & \multicolumn{2}{|c|}{$\begin{array}{l}\text { Tuber firmness } \\
\text { (N/mm) }\end{array}$} & \multicolumn{4}{|c|}{ Tuber dry matter (\%) Specific gravity } \\
\hline & & 2018 & 2019 & 2018 & 2019 & 2018 & 2019 & 2018 & 2019 \\
\hline \multicolumn{10}{|c|}{ Main effect of $\mathrm{B}\left(\mathrm{mg} \mathrm{l}^{-1}\right)$} \\
\hline Control & & $5.70^{c}$ & $5.73^{c}$ & $11.82^{\mathrm{b}}$ & $11.74^{\mathrm{b}}$ & $14.95^{\mathrm{d}}$ & $17.32^{\mathrm{d}}$ & $1.034^{\mathrm{d}}$ & $1.048^{\mathrm{c}}$ \\
\hline 10 & & $9.59^{\mathrm{b}}$ & $9.94^{\mathrm{b}}$ & $11.77^{\mathrm{b}}$ & $11.71^{\mathrm{b}}$ & $16.62^{\mathrm{c}}$ & $19.82^{c}$ & $1.051^{\mathrm{c}}$ & $1.062^{\mathrm{b}}$ \\
\hline 20 & & $10.84^{\mathrm{a}}$ & $10.94^{\mathrm{a}}$ & $12.18^{\mathrm{b}}$ & $12.13^{\mathrm{b}}$ & $16.85^{\mathrm{b}}$ & $20.17^{\mathrm{b}}$ & $1.053^{\mathrm{b}}$ & $1.067^{\mathrm{a}}$ \\
\hline 30 & & $10.59^{\mathrm{a}}$ & $10.94^{\mathrm{a}}$ & $13.84^{\mathrm{a}}$ & $13.82^{\mathrm{a}}$ & $17.07^{\mathrm{a}}$ & $20.59^{a}$ & $1.055^{\mathrm{a}}$ & $1.069^{\mathrm{a}}$ \\
\hline \multicolumn{10}{|c|}{ main effect of 6-BA $\left(\mathrm{mg} \mathrm{l}^{-1}\right)$} \\
\hline Control & & $7.09^{c}$ & $7.14^{\mathrm{c}}$ & $11.32^{\mathrm{c}}$ & $11.27^{\mathrm{c}}$ & $15.50^{\mathrm{d}}$ & $18.16^{\mathrm{d}}$ & $1.038^{\mathrm{d}}$ & $1.054^{\mathrm{c}}$ \\
\hline 10 & & $8.09^{\mathrm{c}}$ & $8.40^{\mathrm{bc}}$ & $12.08^{\mathrm{b}}$ & $12.04^{\mathrm{b}}$ & $16.12^{\mathrm{c}}$ & $19.06^{\mathrm{c}}$ & $1.045^{\mathrm{c}}$ & $1.060^{\mathrm{b}}$ \\
\hline 20 & & $9.87^{\mathrm{b}}$ & $9.94^{\mathrm{b}}$ & $12.42^{\mathrm{b}}$ & $12.34^{\mathrm{b}}$ & $16.65^{\mathrm{b}}$ & $19.91^{\mathrm{b}}$ & $1.051^{\mathrm{b}}$ & $1.065^{\mathrm{a}}$ \\
\hline 30 & & $11.68^{\mathrm{a}}$ & $12.09^{\mathrm{a}}$ & $13.79^{\mathrm{a}}$ & $13.75^{\mathrm{a}}$ & $17.22^{\mathrm{a}}$ & $20.76^{\mathrm{a}}$ & $1.058^{\mathrm{a}}$ & $1.067^{\mathrm{a}}$ \\
\hline \multicolumn{10}{|c|}{ Interaction effects } \\
\hline \multicolumn{10}{|c|}{$\mathrm{B}\left(\mathrm{mg} \mathrm{l}^{-1}\right) \quad$ 6-BA $\left(\mathrm{mg} \mathrm{l}^{-1}\right)$} \\
\hline \multirow{4}{*}{ Control } & Control & $3.67^{\mathrm{g}}$ & $3.81^{\mathrm{h}}$ & $10.47^{\mathrm{gh}}$ & $10.30^{\text {gh }}$ & $14.55^{\mathrm{n}}$ & $16.86^{\mathrm{p}}$ & $1.029^{j}$ & $1.045^{\mathrm{i}}$ \\
\hline & 10 & $5.67^{\mathrm{fg}}$ & $5.58^{\mathrm{gh}}$ & $11.33^{\mathrm{fg}}$ & $11.25^{\mathrm{fg}}$ & $14.85^{\mathrm{m}}$ & $17.23^{\circ}$ & $1.033^{\mathrm{i}}$ & $1.048^{\mathrm{i}}$ \\
\hline & 20 & $6.57^{\mathrm{ef}}$ & $6.63^{\mathrm{fg}}$ & $11.40^{\mathrm{fg}}$ & $11.30^{\mathrm{fg}}$ & $15.08^{1}$ & $17.44^{\mathrm{n}}$ & $1.035^{\mathrm{i}}$ & $1.049^{\mathrm{hi}}$ \\
\hline & 30 & $6.90^{\mathrm{ef}}$ & $6.91^{\mathrm{e}-\mathrm{g}}$ & $14.07^{\mathrm{ab}}$ & $14.10^{\mathrm{ab}}$ & $15.34^{\mathrm{k}}$ & $17.76^{\mathrm{m}}$ & $1.038^{\mathrm{h}}$ & $1.051^{\mathrm{ghi}}$ \\
\hline \multirow{4}{*}{10} & Control & $7.87^{\mathrm{d}-\mathrm{f}}$ & $7.97^{\mathrm{d}-\mathrm{g}}$ & $10.27^{\mathrm{h}}$ & $10.25^{\mathrm{h}}$ & $15.65^{\mathrm{j}}$ & $18.21^{1}$ & $1.039^{\mathrm{h}}$ & $1.055^{\text {gh }}$ \\
\hline & 10 & $8.70^{\mathrm{de}}$ & $9.23^{\mathrm{c}-\mathrm{e}}$ & $11.67^{\mathrm{ef}}$ & $11.60^{\mathrm{ef}}$ & $16.24^{\mathrm{h}}$ & $19.34^{\mathrm{i}}$ & $1.046^{\mathrm{f}}$ & $1.062^{\mathrm{ef}}$ \\
\hline & 20 & $9.57^{\mathrm{cd}}$ & $9.72^{\mathrm{cd}}$ & $11.80^{\mathrm{ef}}$ & $11.70^{\mathrm{ef}}$ & $16.94^{\mathrm{f}}$ & $20.35^{\mathrm{f}}$ & $1.054^{\mathrm{de}}$ & $1.068^{\text {cde }}$ \\
\hline & 30 & $12.20^{\mathrm{b}}$ & $12.85^{\mathrm{b}}$ & $13.33^{\mathrm{bcd}}$ & $13.30^{\mathrm{bcd}}$ & $17.63^{c}$ & $21.37^{\mathrm{c}}$ & $1.063^{\mathrm{b}}$ & $1.064^{\mathrm{ef}}$ \\
\hline \multirow{4}{*}{20} & Control & $8.40^{\mathrm{de}}$ & $8.38^{\mathrm{d}-\mathrm{f}}$ & $11.53^{\mathrm{f}}$ & $11.50^{f}$ & $15.84^{\mathrm{i}}$ & $18.55^{\mathrm{k}}$ & $1.042^{\mathrm{g}}$ & $1.057^{\mathrm{fg}}$ \\
\hline & 10 & $9.00^{\mathrm{de}}$ & $9.39^{c-e}$ & $11.93^{\mathrm{ef}}$ & $11.90^{\mathrm{ef}}$ & $16.55^{\mathrm{g}}$ & $19.64^{\mathrm{h}}$ & $1.048^{\mathrm{f}}$ & $1.065^{\mathrm{de}}$ \\
\hline & 20 & $11.67^{\mathrm{bc}}$ & $11.70^{\mathrm{bc}}$ & $12.60^{\mathrm{de}}$ & $12.50^{\mathrm{de}}$ & $17.13^{\mathrm{e}}$ & $20.74^{\mathrm{e}}$ & $1.056^{\mathrm{cd}}$ & $1.071^{\mathrm{bcd}}$ \\
\hline & 30 & $14.30^{\mathrm{a}}$ & $14.29^{\mathrm{a}}$ & $12.67^{\mathrm{de}}$ & $12.60^{\mathrm{de}}$ & $17.86^{\mathrm{b}}$ & $21.74^{\mathrm{b}}$ & $1.064^{\mathrm{ab}}$ & $1.076^{\mathrm{ab}}$ \\
\hline \multirow{4}{*}{30} & Control & $8.40^{\mathrm{de}}$ & $8.38^{\mathrm{d}-\mathrm{f}}$ & $13.00^{\mathrm{cd}}$ & $13.01^{\mathrm{cd}}$ & $15.96^{\mathrm{i}}$ & $19.03^{j}$ & $1.043^{\mathrm{g}}$ & $1.058^{\mathrm{fg}}$ \\
\hline & 10 & $9.00^{\mathrm{de}}$ & $9.39^{\mathrm{c}-\mathrm{e}}$ & $13.40^{\mathrm{bcd}}$ & $13.42^{\mathrm{bcd}}$ & $16.83^{\mathrm{f}}$ & $20.05^{\mathrm{g}}$ & $1.052^{\mathrm{e}}$ & $1.066^{\mathrm{de}}$ \\
\hline & 20 & $11.67^{\mathrm{bc}}$ & $11.70^{\mathrm{bc}}$ & $13.87^{\mathrm{bc}}$ & $13.86^{\mathrm{bc}}$ & $17.44^{\mathrm{d}}$ & $21.12^{\mathrm{d}}$ & $1.058^{\mathrm{c}}$ & $1.073^{\mathrm{abc}}$ \\
\hline & 30 & $13.30^{\mathrm{a}}$ & $14.29^{\mathrm{a}}$ & $15.07^{\mathrm{a}}$ & $15.00^{\mathrm{a}}$ & $18.06^{\mathrm{a}}$ & $22.16^{\mathrm{a}}$ & $1.066^{\mathrm{a}}$ & $1.079^{\mathrm{a}}$ \\
\hline
\end{tabular}

-Values having the same alphabetical letter (s) in common, within each column, do not significantly differ, using the revised L.S.D. test at $\mathbf{0 . 0 5}$ level of probability.

Data presented in Table (3) indicated that foliar application with BA as cytokinin gave higher values for previous parameters than those obtained for the untreated plants. The highest mean values obtained with the treatment of $30 \mathrm{mg} . \mathrm{l}^{-1}$ cytokinin. Comparing with the control treatment, which recorded the lowest values. The highest value was $(11.68,13.79,17.22$, and 1.058 ) for potato chips defect (\%), tuber firmness, tuber dry weight $(\%)$, and specific gravity, respectively during both seasons.

As for the interaction between various concentrations of both variables under the study, the results tabulated in Table (3) demonstrated that the treated plants with $30 \mathrm{mg} .1^{-1}$ boron combined with 30 mg. $1^{-1}$ BA, showed the highest mean values for all characters (i.e. potato chips defect (\%), tuber firmness, tuber dry weight (\%), and specific gravity) compared to the other treatments during both seasons of the study. Potato chips defect $(\%)$ recorded 13.30 and $14.29 \%$, tuber firmness recorded 15.07 and $15.00 \mathrm{~N} / \mathrm{mm}$, tuber dry matter recorded 18.06 and $22.16 \%$, and specific gravity were 1.066 and 1.079 during both seasons.

3.3. Tuber chemical quality characteristics

The comparison among the means of the various combined treatments of boron and BA as shown in Table (4) has reflected significant differences between the average values of starch, tuber sugars, TSS, and ascorbic acid of potato tuber during both seasons of 2018 and 2019. 
Regarding the effect of foliar application of boron, the data in Table (4) revealed that the addition of all levels significantly increased the mean values of starch, tuber sugars, TSS, and ascorbic acid in potato tubers as compared to the control treatment. In other words; the highest values (42.82 and $45.29 \%$ ) for starch, $(2.82$ and $3.12 \%)$ for reducing sugar, (4.30 and $4.12 \%$ ) for non-reducing sugar, (7.12 and $7.24 \%)$ for total sugars, (7.48 and 7.59\%) for TSS\% and (19.62 and $21.61 \mathrm{mg} / 100 \mathrm{~g}$ ) for ascorbic acid, respectively during 2018 and 2019 seasons realized for the $30 \mathrm{mg} . \mathrm{l}^{-}$ 1. In the plant, boron plays a major role in the translocation and production of sugars. In the presence of boron, simple organic sugars (Glucose 1-P) will form carbohydrates and complex sugar molecules. In the absence of boron, these simple sugars will form phenols (Quinone phenols), which will accumulate, attract insects and increase disease pressure. When boron is deficient in tissue cambial cells cease to divide but cell elongation continues in growing zones, and as a result, phloem and xylem cells are displaced from their original position so which will leads to the inactivation of vascular tissue. Inactivation of phloem cells leads to a failure of translocation of carbohydrates and sugars to tubers. These results are in agreement with Manjunath et al. (2018), who indicated that using boron increased reducing, non-reducing, total sugar and TSS\%. 
(JAAR) Volume: 26 (2)

Table (4). Average values of some quality determination of potato tubers cv. 'Hermes' characteristics as affected by foliar application with Boron (B), Cytokinin (6-BA) and their combinations during the summer seasons of 2018 and 2019.

\begin{tabular}{|c|c|c|c|c|c|c|c|c|c|c|c|c|c|}
\hline \multirow{3}{*}{\multicolumn{2}{|c|}{ Treatments }} & \multicolumn{12}{|c|}{ Tuber quality } \\
\hline & & \multicolumn{2}{|c|}{ Starch } & \multicolumn{2}{|c|}{ Reducing sugars } & \multicolumn{2}{|c|}{ Non-reducing sugars } & \multicolumn{2}{|c|}{ Total sugars } & \multicolumn{2}{|c|}{ TSS \% } & \multirow{2}{*}{\multicolumn{2}{|c|}{ Ascorbic acid (mg/100g }} \\
\hline & & 2018 & 2019 & 2018 & 2019 & 2018 & 2019 & 2018 & 2019 & & & & \\
\hline \multicolumn{14}{|c|}{ B mg.l $\mathrm{l}^{-1}$ (main effect) } \\
\hline Control & & $40.28^{d}$ & $41.73^{\mathrm{d}}$ & $2.10^{\mathrm{d}}$ & $2.29^{\mathrm{d}}$ & $3.73^{\mathrm{d}}$ & $3.81^{\mathrm{c}}$ & $5.83 \mathrm{~d}$ & $6.10^{\mathrm{d}}$ & $6.57^{\mathrm{d}}$ & $6.77^{\mathrm{d}}$ & $17.82^{\mathrm{d}}$ & $18.96^{\mathrm{d}}$ \\
\hline 10 & & $42.18^{c}$ & $44.50^{c}$ & $2.67^{\mathrm{c}}$ & $2.93^{\mathrm{c}}$ & $4.16^{\mathrm{c}}$ & $4.03^{\mathrm{b}}$ & $6.83^{\mathrm{c}}$ & $6.97^{\mathrm{c}}$ & $7.25^{\mathrm{c}}$ & $7.34^{\mathrm{c}}$ & $19.21^{\mathrm{c}}$ & $21.06^{\mathrm{c}}$ \\
\hline 20 & & $42.50^{\mathrm{b}}$ & $44.93^{\mathrm{b}}$ & $2.74^{b}$ & $3.00^{\mathrm{b}}$ & $4.24^{\mathrm{b}}$ & $4.06^{\mathrm{b}}$ & $6.98^{b}$ & $7.06^{\mathrm{b}}$ & $7.40^{\mathrm{b}}$ & $7.47^{b}$ & $19.42^{\mathrm{b}}$ & $21.34^{\mathrm{b}}$ \\
\hline 30 & & $42.82^{\mathrm{a}}$ & $45.29^{\mathrm{a}}$ & $2.82^{\mathrm{a}}$ & $3.12^{\mathrm{a}}$ & $4.30^{\mathrm{a}}$ & $4.12^{\mathrm{a}}$ & $7.12^{\mathrm{a}}$ & $7.24^{\mathrm{a}}$ & $7.48^{\mathrm{a}}$ & $7.59^{\mathrm{a}}$ & $19.62^{\mathrm{a}}$ & $21.61^{\mathrm{a}}$ \\
\hline \multicolumn{14}{|c|}{ 6-BA mg. $\mathrm{l}^{-1}$ (main effect) } \\
\hline Control & & $40.87^{\mathrm{d}}$ & $42.63^{\mathrm{d}}$ & $2.29^{\mathrm{d}}$ & $2.47^{\mathrm{d}}$ & $3.88^{\mathrm{d}}$ & $3.90^{\mathrm{d}}$ & $6.16^{\mathrm{d}}$ & $6.37^{\mathrm{d}}$ & $6.97^{\mathrm{c}}$ & $7.18^{\mathrm{c}}$ & $18.26^{\mathrm{d}}$ & $19.63^{\mathrm{d}}$ \\
\hline 10 & & $41.70^{\mathrm{c}}$ & $43.60^{c}$ & $2.48^{\mathrm{c}}$ & $2.72^{\mathrm{c}}$ & $4.05^{\mathrm{c}}$ & $3.95^{\mathrm{c}}$ & $6.53^{\mathrm{c}}$ & $6.68^{c}$ & $7.04^{\mathrm{b}}$ & $7.24^{\mathrm{c}}$ & $18.74^{\mathrm{c}}$ & $20.41^{\mathrm{c}}$ \\
\hline 20 & & $42.22^{\mathrm{b}}$ & $44.60^{\mathrm{b}}$ & $2.68^{b}$ & $2.96^{\mathrm{b}}$ & $4.21^{b}$ & $4.04^{\mathrm{b}}$ & $6.89^{\mathrm{b}}$ & $6.99^{b}$ & $7.32^{\mathrm{a}}$ & $7.52^{b}$ & $19.29^{\mathrm{b}}$ & $21.12^{\mathrm{b}}$ \\
\hline 30 & & $42.99^{\mathrm{a}}$ & $45.61^{\mathrm{a}}$ & $2.89^{\mathrm{a}}$ & $3.20^{\mathrm{a}}$ & $4.30^{\mathrm{a}}$ & $4.13^{\mathrm{a}}$ & $7.19^{\mathrm{a}}$ & $7.33^{\mathrm{a}}$ & $7.36^{\mathrm{a}}$ & $7.59^{\mathrm{a}}$ & $19.78^{\mathrm{a}}$ & $21.81^{\mathrm{a}}$ \\
\hline \multicolumn{14}{|c|}{ Interaction effects } \\
\hline \multirow{4}{*}{ Control } & Control & $39.76^{1}$ & $41.13^{\mathrm{p}}$ & $1.99^{\circ}$ & $2.14^{\mathrm{m}}$ & $3.63^{1}$ & $3.76^{j}$ & $5.62^{\circ}$ & $5.90^{\circ}$ & $6.48^{1}$ & $6.72^{\circ}$ & $17.55^{\circ}$ & $18.16^{\mathrm{p}}$ \\
\hline & 10 & $40.35^{\mathrm{k}}$ & $41.52^{\circ}$ & $2.06^{\mathrm{n}}$ & $2.23^{1}$ & $3.71^{\mathrm{kl}}$ & $3.78^{\mathrm{ij}}$ & $5.77^{\mathrm{n}}$ & $6.00^{\mathrm{n}}$ & $6.54^{\mathrm{k}}$ & $6.76^{\circ}$ & $17.71^{\mathrm{n}}$ & $18.96^{\circ}$ \\
\hline & 20 & $40.34^{\mathrm{k}}$ & $41.93^{n}$ & $2.14^{\mathrm{m}}$ & $2.35^{\mathrm{k}}$ & $3.76^{\mathrm{jk}}$ & $3.84^{\text {hi }}$ & $5.90^{\mathrm{m}}$ & $6.19^{\mathrm{m}}$ & $6.57^{\mathrm{k}}$ & $6.84^{n}$ & $17.92^{\mathrm{m}}$ & $19.21^{n}$ \\
\hline & 30 & $40.65^{\mathrm{jk}}$ & $42.33^{\mathrm{m}}$ & $2.22^{1}$ & $2.44^{\mathrm{j}}$ & $3.83^{\mathrm{jk}}$ & $3.85^{\mathrm{h}}$ & $6.04^{1}$ & $6.29^{1}$ & $6.68^{j}$ & $6.90^{\mathrm{m}}$ & $18.11^{1}$ & $19.51^{\mathrm{m}}$ \\
\hline \multirow{4}{*}{10} & Control & $40.91^{\mathrm{j}}$ & $42.73^{1}$ & $2.33^{\mathrm{k}}$ & $2.50^{\mathrm{ij}}$ & $3.88^{\mathrm{i}}$ & $3.91^{\text {gh }}$ & $6.20^{\mathrm{k}}$ & $6.41^{\mathrm{k}}$ & $6.97^{\mathrm{de}}$ & $7.20^{1}$ & $18.29^{\mathrm{k}}$ & $19.84^{1}$ \\
\hline & 10 & $41.85^{\mathrm{h}}$ & $43.93^{\mathrm{i}}$ & $2.54^{\mathrm{i}}$ & $2.80^{\mathrm{g}}$ & $4.10^{\mathrm{fg}}$ & $4.00^{\text {def }}$ & $6.64^{h}$ & $6.80^{\mathrm{i}}$ & $7.10^{\mathrm{h}}$ & $7.25^{\mathrm{k}}$ & $18.88^{\mathrm{h}}$ & $20.61^{\mathrm{i}}$ \\
\hline & 20 & $42.55^{\mathrm{ef}}$ & $45.09^{f}$ & $2.78^{\mathrm{f}}$ & $3.08^{\mathrm{e}}$ & $4.28^{\mathrm{cd}}$ & $4.06^{\mathrm{cd}}$ & $7.06^{\mathrm{e}}$ & $7.14^{\mathrm{f}}$ & $7.48^{\text {de }}$ & $7.60^{\mathrm{f}}$ & $19.57^{\mathrm{e}}$ & $21.48^{\mathrm{f}}$ \\
\hline & 30 & $43.43^{\mathrm{bc}}$ & $46.24^{\mathrm{c}}$ & $3.03^{c}$ & $3.37^{\mathrm{c}}$ & $4.40^{\mathrm{b}}$ & $4.15^{\mathrm{b}}$ & $7.43^{c}$ & $7.51^{\mathrm{c}}$ & $7.45^{\mathrm{e}}$ & $7.69^{\mathrm{e}}$ & $20.09^{c}$ & $22.31^{\mathrm{c}}$ \\
\hline \multirow{4}{*}{20} & Control & $41.25^{\mathrm{i}}$ & $43.13^{\mathrm{k}}$ & $2.37^{\mathrm{k}}$ & $2.53^{\mathrm{i}}$ & $3.97^{\mathrm{h}}$ & $3.94^{\mathrm{fg}}$ & $6.34^{j}$ & $6.47^{\mathrm{k}}$ & $7.23^{\mathrm{g}}$ & $7.32^{\mathrm{j}}$ & $18.51 \mathrm{j}$ & $20.13^{\mathrm{k}}$ \\
\hline & 10 & $42.17^{\mathrm{g}}$ & $44.33^{\mathrm{h}}$ & $2.62^{\mathrm{h}}$ & $2.87^{\mathrm{g}}$ & $4.16^{\mathrm{ef}}$ & $4.00^{\mathrm{def}}$ & $6.78^{\mathrm{g}}$ & $6.88^{\mathrm{h}}$ & $7.21^{\mathrm{g}}$ & $7.39^{\mathrm{i}}$ & $19.09^{\mathrm{g}}$ & $20.89^{\mathrm{h}}$ \\
\hline & 20 & $42.86^{\mathrm{de}}$ & $45.53^{\mathrm{e}}$ & $2.87^{\mathrm{e}}$ & $3.15^{\mathrm{e}}$ & $4.37^{\mathrm{bc}}$ & $4.12^{\mathrm{bc}}$ & $7.24^{\mathrm{d}}$ & $7.27^{\mathrm{e}}$ & $7.60^{\mathrm{bc}}$ & $7.75^{\mathrm{d}}$ & $19.79^{d}$ & $21.77^{\mathrm{e}}$ \\
\hline & 30 & $43.70^{\mathrm{b}}$ & $46.73^{b}$ & $3.11^{\mathrm{b}}$ & $3.45^{\mathrm{b}}$ & $4.46^{\mathrm{ab}}$ & $4.19^{b}$ & $7.57^{\mathrm{b}}$ & $7.63^{\mathrm{b}}$ & $7.54^{\mathrm{cd}}$ & $7.80^{\mathrm{c}}$ & $20.27^{\mathrm{b}}$ & $22.57^{b}$ \\
\hline \multirow{4}{*}{30} & Control & $41.55^{\mathrm{ef}}$ & $43.52^{\mathrm{j}}$ & $2.46^{\mathrm{j}}$ & $2.70^{\mathrm{h}}$ & $4.02^{\mathrm{gh}}$ & $3.97^{\mathrm{efg}}$ & $6.48^{\mathrm{i}}$ & $6.68^{j}$ & $7.18^{\mathrm{g}}$ & $7.47^{h}$ & $18.68^{\mathrm{i}}$ & $20.37^{\mathrm{j}}$ \\
\hline & 10 & $42.42^{\mathrm{fg}}$ & $44.64^{\mathrm{g}}$ & $2.70^{\mathrm{g}}$ & $2.99^{\mathrm{f}}$ & $4.23^{\mathrm{de}}$ & $4.03^{\mathrm{de}}$ & $6.94^{\mathrm{f}}$ & $7.02^{\mathrm{g}}$ & $7.30^{\mathrm{f}}$ & $7.54^{\mathrm{g}}$ & $19.28^{\mathrm{f}}$ & $21.18^{\mathrm{g}}$ \\
\hline & 20 & $43.13^{\mathrm{cd}}$ & $45.86^{\mathrm{d}}$ & $2.93^{\mathrm{d}}$ & $3.26^{\mathrm{d}}$ & $4.41^{\mathrm{b}}$ & $4.12^{\mathrm{bc}}$ & $7.35^{\mathrm{c}}$ & $7.38^{d}$ & $7.64^{\mathrm{b}}$ & $7.88^{b}$ & $19.89^{\mathrm{d}}$ & $22.04^{\mathrm{d}}$ \\
\hline & 30 & $44.17^{\mathrm{a}}$ & $47.13^{\mathrm{a}}$ & $3.20^{\mathrm{a}}$ & $3.53^{\mathrm{a}}$ & $4.51^{\mathrm{a}}$ & $4.35^{\mathrm{a}}$ & $7.71^{\mathrm{a}}$ & $7.88^{a}$ & $7.75^{a}$ & $7.95^{\mathrm{a}}$ & $20.64^{\mathrm{a}}$ & $22.85^{\mathrm{a}}$ \\
\hline
\end{tabular}

-Values having the same alphabetical letter (s) in common, within each column, do not significantly differ, using the revised L.S.D. test at 0.05 level of probability. 
Data in Table (4) detected that all treatments had a pronounced positive effect on the mean values on tuber quality under investigation as compared to the untreated plants. All traits increased with increasing levels of BA until to $30 \mathrm{mg} \cdot \mathrm{l}^{-1}$. Foliar application of boron at $30 \mathrm{mg} . \mathrm{l}^{-1}$, recorded the highest mean values offer mentioned tuber chemical parameters during both seasons. These results are following that obtained by Rosin et al. (2003) on potato, who indicated that increasing of cytokinin concentration owing to antisense suppression of potato box gene, brought about the higher increments of starch accumulation. In addition, El-Shraiy and Hegazi (2010) reported that cytokinin at $10 \mathrm{ppm}$ treatment, significantly increased the total soluble sugars of potato tubers. Moreover, On tomato, Mousawinejad et al. (2014) reported that foliar application of CPPU as cytokinin at 10 and $20 \mathrm{mg}$ $\mathrm{I}^{-1}$ on the fruit affected, significantly, biochemical characteristics such as sugar, treatable acids, and vitamin $\mathrm{C}$ contents.

Concerning interaction effects between both variables of the present study, the tabulated results (Table 4) reflected that as both independent variable concentrations increased; the given traits, average values increased significantly $(p \leq 0.05)$ in a direct proportionate relationship, especially when potato plants were foliar treated with $30 \mathrm{mg} . \mathrm{l}^{-1}$ of boron in combination with $30 \mathrm{mg} . \mathrm{l}^{-1}$ of $\mathrm{BA}$ as cytokinin; the particular treatment gave rise to the highest significant average values for fruit content of starch as 44.17 and $47.13 \%$, reducing sugar as 3.20 and $3.53 \%$, nonreducing sugars as 4.51 and $4.35 \%$, total sugars as 7.71 and $7.88 \%$, TSS as 7.75 and $7.95 \%$, and ascorbic acid as 20.64 and $22.85 \mathrm{mg} / 100 \mathrm{~g}$ compare with average values of control plants' measurements, which were 39.76 and $41.13 \%$ for starch, 1.99 and $2.14 \%$ for reducing sugar, 3.63 and $3.76(\%)$ for non-reducing sugar, 5.62 and $5.90(\%)$ for total sugar, and 6.48 and $6.72 \%$ for TSS and finally 17.55 and $18.16 \mathrm{mg} / 100 \mathrm{~g}$ for ascorbic acid during both seasons of the study 2018 and 2019, each in turn.

\subsection{Tubers $N, P, K$, and $B$ contents}

Nutritional elements of potato tubers; Nitrogen, Phosphorus, Potassium, and Boron concentrations as affected by the treatments under investigations presented in Table (5). Results in Table (5) demonstrated that; foliar application of boron with different levels significantly increased the mean values of all nutritional elements over those obtained for the control treatment. The highest mean values of all nutrients content recorded at the level of $30 \mathrm{mg} \cdot \mathrm{l}^{-1}$. Comparing with the control treatment, the rate of increases was accounted to be $66.94,43.83,42.24$, and 12.77 (\%) over the control treatment for N, P, K, and B, respectively in the season of 2018 , and the same trend happened in the second season. 
Table (5). Average values of some chemical determination of potato tubers cv. 'Hermes' characteristics as affected by foliar application with Boron (B), cytokinin (6-BA) and their combinations during the summer seasons of 2018 and 2019.

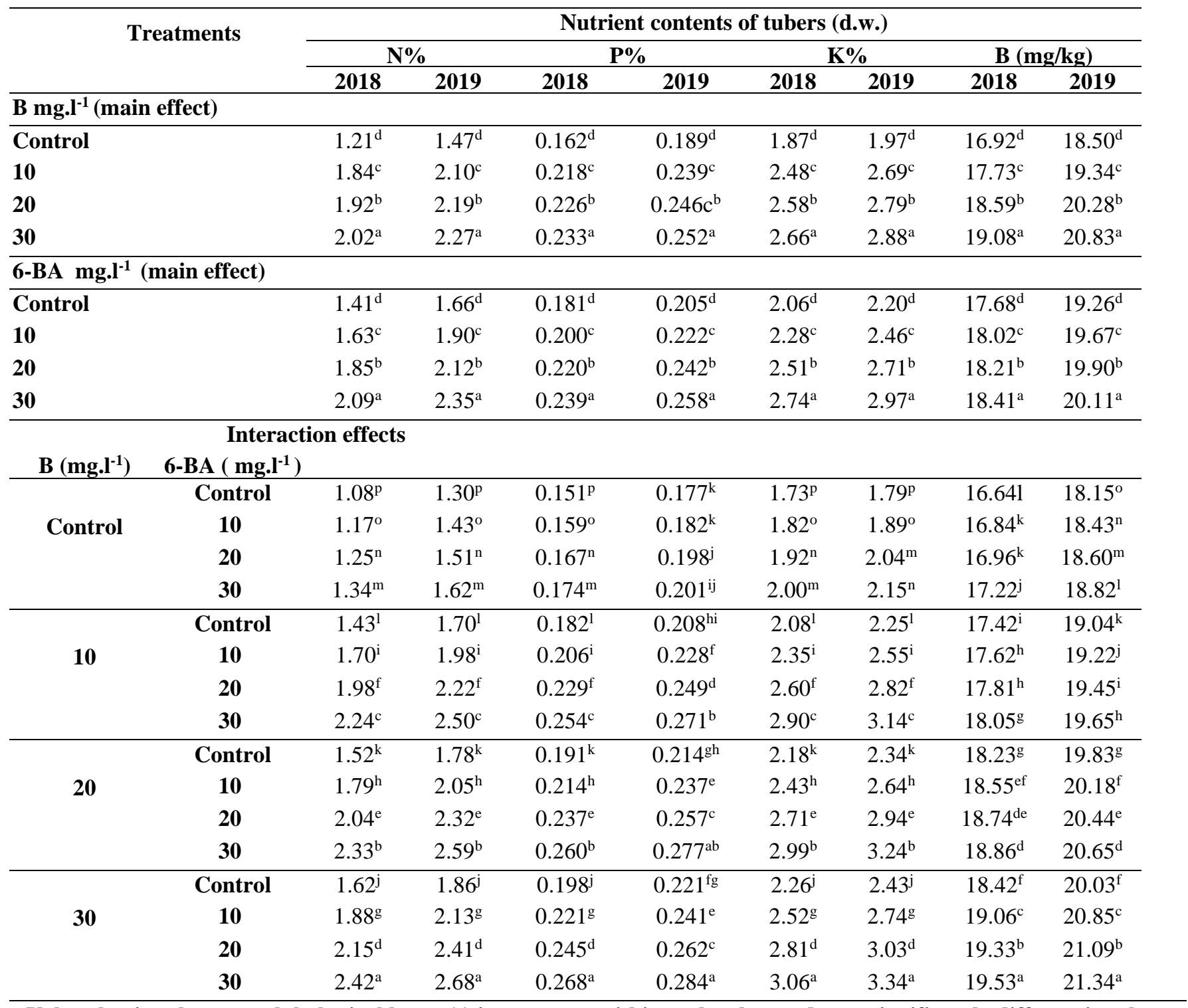

-Values having the same alphabetical letter (s) in common, within each column, do not significantly differ, using the revised L.S.D. test at 0.05 level of probability.

The increase of $\mathrm{N}$ content maybe returns to the role of $\mathrm{B}$ in the synthesis of amino acids and proteins, while the increase in $\mathrm{P}$ content may be attributed to the role of $\mathrm{B}$ in root tips, whereas membrane-bound ATPase activity influenced by Boron levels in the root (Canada 2002). The increase in $K$ content may related to the synergism relationship between $\mathrm{K}$ and $\mathrm{B}$ at sugar and carbohydrate transport (Mengle and Kirkby 1978). The increase in B content certainly due to the increase of boron levels in the media. Similar results were obtained by El-Banna and Abd El-Salam (2005) who indicated that treated potato plants with different foliar spraying rates of B (50 and $75 \mathrm{ppm}$ ) significantly, recorded the highest concentrations of $\mathrm{N}, \mathrm{K}$, and $\mathrm{B}$ in plants. Also, El-Mahdy (2007) showed that foliar spray of $\mathrm{B}$ at a rate of $75 \mathrm{ppm}$ increased pepper N, P, K, and $\mathrm{B}$ and its uptake. Moreover, El-Said (2009) showed that foliar application of boron at 100 ppm significantly increases $\mathrm{N}$, $\mathrm{P}$, and $\mathrm{K}$ contents in sweet pepper plant leave. In the same line, El-Dissoky and Abdel-Kadar (2013) found that the uptake of $\mathrm{N}, \mathrm{P}$, and $\mathrm{K}$ significantly increased by foliar B application in the potato plant.

The different comparisons tabulated in Table (5) indicated that the average values of all nutritional elements in potato tubers significantly increased because of spray potato plant with the different levels of BA as cytokinin. The highest mean values for the 
previously mentioned traits found to be associated with the addition of $30 \mathrm{mg} \cdot \mathrm{l}^{-1}$ for $\mathrm{N}, \mathrm{P}, \mathrm{K}$, and $\mathrm{B}$ elements. The average mean values of all nutritional elements of potato for both seasons significantly increased over those obtained for the control treatment. The highest mean values recorded as (2.09 and 2.35\%) for $\mathrm{N}$ content, $(0.239$ and $0.258 \%)$ for $\mathrm{P}$ content, $(2.74$ and $2.97 \%$ ) for $\mathrm{K}$ content and (18.41 and $20.11 \mathrm{mg} / \mathrm{kg}$ ) for B content, respectively during 2018 and 2019 seasons.

Nutritional element concentrations in potato tuber as affected by the interaction between all treatments under study tabulated in Table (5). Data of this table revealed that the mean values of the most nutritional elements in potato tuber tended to increase over the control treatment because of the interaction between the studied treatments. In this respect, the most suitable treatment which realized the highest values (2.42, 0.268, 3.06, and 19.53 for $\mathrm{N} \%, \mathrm{P}, \mathrm{K} \%$ and $\mathrm{B}$ $\mathrm{mg} / \mathrm{kg}$ ) during 2018 season were connected with 30 mg..$^{-1}$ boron +30 mg. $1^{-1}$ BA. Besides, these mean values tended to increase than those obtained for the control treatment (1.08, 0.151, 1.73, and 16.64 for $\mathrm{N}, \mathrm{P}$, and $\mathrm{K}$ $(\%)$, and $\mathrm{B} \mathrm{mg} / \mathrm{kg}$, respectively in 2018). The same trend was true during the 2019 season.

Generally, the foliar application of both boron and cytokinin solution had a significant effect on potato yield, tuber physical and chemical quality and nutritional content. Therefore, the present study recommend a foliar application of boron plus cytokinin at rate of $30 \mathrm{mg} \mathrm{l}^{-1}$ to obtain the highest yield of potato and good quality tubers.

\section{RECOMMENDATIONS}

Practically, from the above-mentioned results and under the conditions of this research, it could concluded that foliar application of boron at $30 \mathrm{mg} \mathrm{l}^{-1}$ and cytokinin at $30 \mathrm{mg} \mathrm{l}^{-1}$, is the appropriate combination of both independent variables for the best growth characters, yield, and its components and chemical composition.

Further research on cytokinin as 6-benzyl adenine is important because of its high content of unprocessed natural nutrients necessary for plant growth and quality; also, it protects the environment from pollution.

\section{REFERENCES}

AOAC (1992). Official methods of analysis of the Association of Official Analytical Chemists, $15^{\text {Th }}$ Ed. Published by the Association of Official Analytical Chemists III. North Nineteenth suite 210 Arlington, Virginia 2220/U.S.A.

Awad, E. M. M. and S. A. A. Mansour (2007). Growth, yield, and quality of potato as affected by some antioxidants. J. Agric. Sci. Mansoura Univ., 32 (8): 6661-6669.

Bricker, B. (1991). MSTATC: A Micro Computer Program from the Design Management and
Analysis of Agronomic Research Experiments. Michigan State Univ., USA.

Canada, A. L. (2002). Fact Sheet No. 90: Boron as a Plant Nutrient. A \& L Canada Laboratories, 2136 Jetstream Rd., London, ON N5V 3P5, 519-457-2575. (C.F. www.alcanada.com).

Carter, M. R., and E. G. Gregorich (2008). Soil sampling and methods of Analysis. Second Edition. Canadian Soc. Soil Sci., Boca Raton, FL: CRC Press, 1264 pages.

Chapman, H. D., and P. F. Pratt (1978). Methods of analysis for soils, plants, and waters. Univ. of California, Div. Agric. Sci., Priced publication.

Dinesh, K., R. Ezekiel, B. Singh, and I. Ahmed (2005). Conversion table for specific gravity dry matter and starch content from under water weight of potatoes grown in North India plains. Potato J., 32 (1-2): 79-84.

Duncan, D B. (1955). Multiple range and multiple F tests. Biometrics 11:1-42.

El-Banna, E. N. and H. Z. Abd El-Salam (2005). Response of potato plants for different sources of potassium with different foliar rates of boron and molybdenum. J. Agric. Sci. Mansoura Univ., 30(10): 6221-6233.

El-Dissoky, R. A. and A. E. S. Abdel-Kadar (2013). Effect of boron as a foliar application on some potato's cultivars under Egyptian alluvial soil conditions. Res. J. Agric. \& Biol. Sci., 9(5): 232-240.

El-Mahdy, R.E. (2007). Effect of heavy nitrogen application on pepper plant (Capsicum annuum). M. Sci. Thesis Fac. Agric. Mansoura Univ., Egypt.

El-Said, M. E. (2009). Effect of boron foliar application and different combinations of mineral and organic nitrogen fertilization on growth, chemical composition, and yield of sweet pepper (Capsicum annuum L.). J. Agric. Sci., Mansoura Univ., 34(5): 48414860.

El-Shraiy, A. M. and A. M. Hegazi (2010). Influence of JA and CPPU on growth, yield and $\alpha$ amylase activity in potato plant (Solanum tuberosum L.). Aust. J. Basic and Appl. Sci., 4(2): 160-170.

Frito Lay Company (1999). Potato sending Manual. Operations quality system department. Leicester, United Kingdom.

Gomez, K. A., and A. A. Gomez (1984). Statistical Procedures for Agricultural Research. John Wiley and Sons, Inc., New York.pp:680.

Kolachevskaya, O. O., L. I. Sergeeva, K. Floková, I. A. Getman, S. N. Lomin, V. V. Alekseeva and G. A. Romanov (2017). Auxin synthesis gene tms 1 driven by tuber-specific promoter alters hormonal status of transgenic potato plants and their responses 
to exogenous phytohormones. Pl. Cell Repts, 36(3): 419-435.

Kolachevskaya, O. O., V. V. Alekseeva, L. I. Sergeeva, E. B. Rukavtsova, I. A. Getman, D. Vreugdenhil and G. A. Romanov (2015). Expression of auxin synthesis gene tms1 under control of tuber-specific promoter enhances potato tuberization in vitro. J. of integr. Pl. Biol., 57(9): 734-744.

Li, C., and A.A. Kader. 1989. Residual effects of controlled atmospheres on postharvest physiology and quality of strawberries. J. Amer. Soc. Hort. Sci., 114(4): 629-634.

Liu, J. and C.H. Xie (2001). Correlation of cell division and cell expansion to potato microtuber growth in vitro. Pl. Cell Tiss. \& Organ Cult., 67: 159-164.

Majiid, H., S. Minali, M. Almasi and Y. Mostofi (2011). Total soluble solids, titrable acidity and ripening index of tomato in various storage conditions. Aust. J. Basic. Appl. Sci., 5(12):1723- 1726.

Malik, C. P. and M. B. Singh (1980). Plant Enzymology and Histo-Enzymology- A text Manual, PP. 276- 277, Kalyani Publishers, New Delhi, India.

Manjunath, R. P., V. M. Anjanappa, G. K. Ramegowda, S. Anilkumar and P.S. Prasad (2018). Influence of foliar spray of micronutrient formulation on quality and shelf life of potato (Solanum tuberosum L.). Intl. J. Pure. Appl. BioSci., 6(1): 660-665.

Mengle m K. and E. A. Kirkby (1978). "Principles of Plant Nutrition." Int. Potash Inst., Berne, Sweitzerland.

Miller, C.O., F. Skoog, M. H Saltza and F. M. Strong (1955) Kinetin, a cell division factor from deoxyribonucleic acid. 1. Amer. Chem. Soc., 77: 1329-1334.

Mok, M. C., D. W. S. Mok, S. C. Dixon, D. J. Armstrong and G. Shaw. (1982). Cytokinin structure-activity relationships and the metabolism of N6- (D2-isopentenyl) adenosine-8-14C in Phaseolus callus cultures. Pl. Physiol., 70:173-178.

Mousawinejad, S., F. Z. Nahandi and A. Baghalzadeh (2014). Effects of CPPU on size and quality of tomato (Solanum lycopersicum L.) fruits. Postharvest Biol. \& Techn., 89 (4): 555-573.

Muthanna, M. A., A. K. Singh, A. Tiwari, V. K. Jain and M. Padhi (2017). Effect of boron and sulphur application on plant growth and yield attributes of potato (Solanum tuberosum L.). Intl. J. Curr. Microbiol. Appl. Sci., 6(10): 399-404.

Njogu, M. K., G. K. Gathungu and P. M. Danie (2015). Comparative effects of foliar application of gibberellic acid and benzylaminopurine on seed potato tuber sprouting and yield of resultant plants. Am. J. Agric. and Forest., 3 (5): 192-201.

Prasad, R., D. Kumar, Y. S. Shivay, and D. S. Rana (2014). Boron in Indian agriculture - a review. Indian Journal of Agronomy, 59(4): 511-517.

Ranganna, S. (1986). Handbook of Analysis and Quality Control for Fruit and Vegetable Products. Tata McGraw-Hill Publishing Company Ltd., New Delhi, India.1112 Pp.

Rosin, F. M., J. K. Hart, H. Van Onckelen and D. J. Hannapel (2003). Suppression of vegetative MADS box gene of potato activates axillary meristem development. Pl. Physiol., 129: 175-180.

Roumeliotis, E., B. Kloosterman, M. Oortwijn, W. Kohlen, H. J. Bouwmeester and R. G. Visser (2012). The effects of auxin and strigolactones on tuber initiation and stolon architecture in potato. J. Exp. Bot., 63:45394547.

Singh, D., P. K. Chhonker and B. S. Dwivedi (2005). Manual on soil plant and water analysis. West Ville publishing house, New Delhi, pp. 200.

Smith, O. (1977). Potatoes: production, storing and processing. The AVI Publishing Company, Westport, Connecticut, USA. Second edition. pp. 222-302.

Takahashi, S., K. Shudo, T. Okamoto, K. Yamada, Y. Isogai (1978). Cytokinin activity of Nphenyl-N0-(4-pyridyl) urea derivatives. Phytochemistry, 17:1201-1207.

Wolf, B. (1971). The determination of boron in soil extracts, plant materials, composts, manures, waters and nutrient solutions. Comm. Soil Sci. and Plant Anal., 2: 363. 


\title{
الملخص العربي
}

\section{إنتاجية وجودة البطاطس متأثرة بالرش الورقي للبورون والسيتوكينين}

\author{
سماهر مالك' - على إبراهيم على عبيدو' - جمال عبد الناصر خليل' -

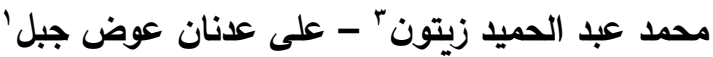

ا قسم الإنتاج النباتي - كلية الزراعة سابا باشا - جامعة الإسكندرية

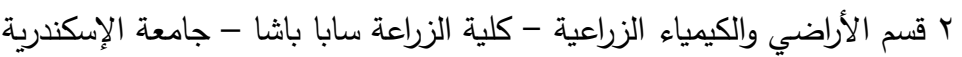

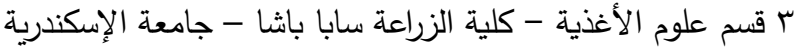

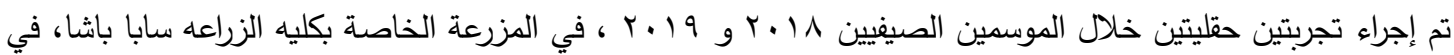
منطقة أبيس ، محافظة الاسكندريه، مصر ، لدراسة تأثير الرش الورقى بمستويات مختلفة من البورون و السيتوكينين على ى الدحصول ، وجودة البطاطس صنف 'Hermes'.

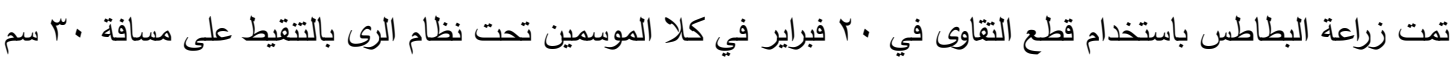

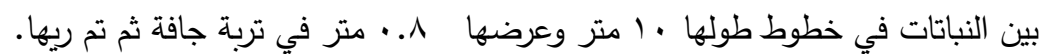
تكونت المعاملات من عاملين الرش الورقي وكان العامل الأول هو البورون (حض البوريك B) بأربعة تركيزات هي: صفر

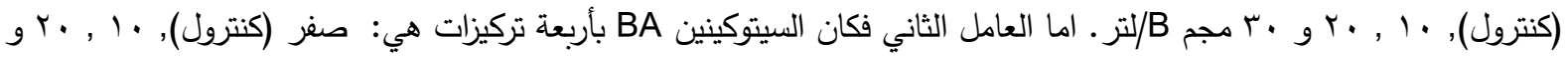

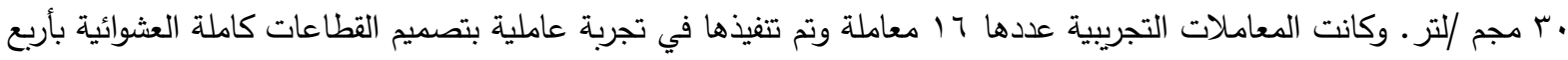

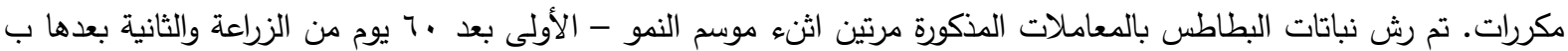

يمكن تلخيص النتائج التي تم الحصول عليها على النحو التالي: التوري اعطى الرش الورقي بالبورون بتركيز • · مجم/لتر اعلى متوسطات قيم لكل من عدد الدرنات/نبات,والوزن الظازج للارنة, عدد الدرنات/• اكجم, محصول الدرنات جرام/نبات, المحصول الكلي للدرنات (طن/فدان) مقارنة بمعاملة الكنترول( عدم الرش) خلال موسمي الدراسة. على الجانب الاخر , سجل الرش الورقي بالسيتوكينين بتركيز ·ـ مجم/تلز اعلى عدد درنات/نبات, الوزن الظازج للدرنة, عدد الدرنات/• ا كجم , الدحصول/نبات (جم) , المحصول الكلي(طن/فدان) مقارنة بمعاملة الكنترول والمعاملات الأخرى خلال

أوضحت النتائج ان الرش الورقي بالبورون عند تركيز •r مجم/تتر أدى الى زيادة ملحوظة لكلا من رقائق البطاطس\% صلابة الدرنات, الوزن الجاف للدرنة و الكثافة النوعية مقارنة بمعاملة الكنترول خلال كلا الموسمين. كما ان الرش الورقي بالسيتوكينين بتركيز •r مجم/لتر اعطى اعلى رقائق للبطاطس \%, صلابة الدرنات, الوزن الجاف للدرنة, الكثافة النوعية مقارنة بمعاملة الكنترول خلال كلا الموسمين.

سجل الرش الورقي بالبورون عند تركيز ·r مجم/لتز افضل النتائج لجودة الدرنات من النشا, السكريات الكلية , المواد الصلبة

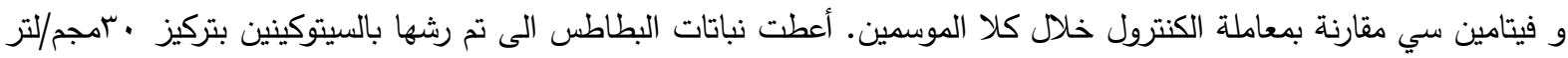
اعلى متوسط قيم النشا, السكريات الكلية والمواد الصلبة وفيتامين سي خلال كلا الموسمين. سجل محتوى الأوراق من النيتروجين, الفوسفور , البوتاسيوم والبورون اعلى قيم عند الرش بتركيز · ب مجم/لتر من البورون والسيتوكينين مقارنة بمعاملة الكنترول في كلا الموسمين.

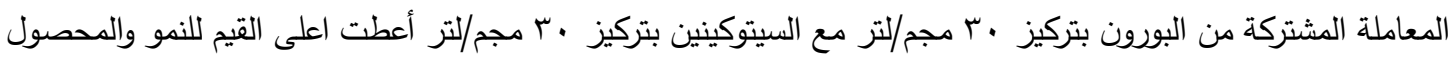

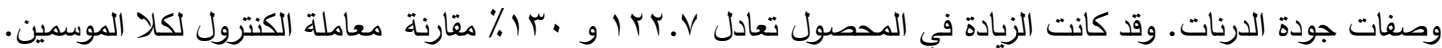

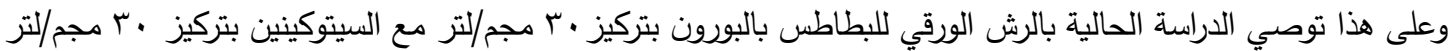

